\title{
PRELIMINARY ANALYSIS ON THE SUCCESS OF COMMUNITY-BASED COMMUNITY ROAD PROGRAM RELATED TO COMMUNITY CHARACTERISTICS, IN PASURUAN CITY
}

\author{
Hitapriya Suprayitno(), Ayu Rahmaniyah ${ }^{2)}$, dan Eko Budi Santosa ${ }^{3)}$ \\ 1) Civil Engineering Dept., Institut Teknologi Sepuluh Nopember, Surabaya \\ 2) Bappeda, Kota Pasuruan, Pasuruan \\ 3) Urban \& Regional Planning Dept., Institut Teknologi Sepuluh Nopember, Surabaya \\ suprayitno.hita@gmail.com
}

\begin{abstract}
As a developing country, Indonesia still has a lot of urban slum areas. Ministry of Public Works and Public Housing create the KOTAKU program, City without Slum. To realize the KOTAKU objective, two projects were conducted the NSUP and the NUSP. Pasuruan City was given the NUSP-2 project, in 2016, covered 11 slum areas, dealt with community road, community sanitation, and community water supply. The success of the community road program had been evaluated. The program was relatively unsuccessful in a coastal area dominated by fisherman settlement. In the next to the coastal area dominated by supporting fishermen supporting an activity, the program was relatively fairly successful. While in urban slum areas dominated by middle-income families, the program was successful.
\end{abstract}

Keywords: infrastructure management, community road, community-based 


\section{INTRODUCTION}

In developing countries, such as Indonesia, the Kampong Areas can still be found a lot in the urban residential area. Kampong Area is a dense residential area, with relatively low-income people. In this kind of community, the daily quality of life depends on the Community Life Quality. This strongly related to the basic needs of the community, i.e. basic public infrastructures, the social public facilities, the community business activity, the community health-related program, the community children related activity, etc. Slum areas still can be found easily. The governments, central down to city or regency, do not have enough manpower to manage those basic community needs. Thus, Community-Based Development needs to be organized and well maintained, for the benefit of the community. This will support the whole upper-level development. A lot of Community-Based Development have been organized in Indonesia focusing on different aspects: infrastructure, tourism, business, facility, etc (Bahar, 2016; Dewi, 2018; Hesna et al, 2018; Kurniasih, Setyoko \& Imron, 2016; Megawati et al, 2019; Prakoso \& Pravita, 2018; PSF, 2013; Rahmaniyah, 2019; Setiawan, 2014).
Infrastructure is capital for regional life. The Basic Principle of Infrastructure Asset Management (IAM) says that infrastructure needs to be well managed through its whole life cycle, in order to be able to well function sustainably, economically, efficiently, effectively and in concordance with green principle. The infrastructure quality is measured based on its performance to execute its function. Its performance is of course, dependent on the physical condition, the load factor and its operational management. Finally, these all depend on infrastructure management quality (Suprayitno, 2014; Suprayitno \& Soemitro, 2018; Suprayitno \& Soemitro 2019). In Indonesia, the physical aspect of real estate and residential are well regulated. They must be equipped with certain infrastructure and facilities, which are regulated also (PerMenPR 10/10, PP 14/16, SNI 03-1733-2004, UU 1/11). Therefore, it is always important to evaluate infrastructure quality.

As a developing country, Indonesia still has a lot of urban slum areas. To overcome this problem, the Ministry of Public Works and Public Housing organized KOTAKU - Kota Tanpa Kumuh (City without Slum Area) program. The objective is to realize a healthy, habitable, and sustainable settlements for slum areas. 
Two series of project were created, i.e. the NSUP - National Slum Upgrading Program and the NUSP - Neighborhood Upgrading and Shelter Project (Cipta Karya 2018; Rahmaniyah, 2019). Pasuruan City was given NUSP-2 Projects covering 11 Kelurahans. All Kelurahans were given community road betterment. It is very important to evaluate the success of this community road program. The main question is whether the road success is related to the Kelurahan Main Characteristics.

This paper presents a preliminary analysis of the success of the communitybased community road program related to community characteristics, in Pasuruan City.

\section{LITERATURE REVIEW}

\subsection{Infrastructure Asset Management}

The IAM is knowledge or program to manage infrastructure along its lifecycle, in order that the infrastructure can well function sustainably, in an economic, efficient and effective way. It must respect the green (sustainability) principal. The pertinent risks must be considered (Suprayitno \& Soemitro, 2018).

\subsection{Infrastructure Quality}

From the point of view of the IAM, the infrastructure is built to execute a certain function. Thus the infrastructure quality measurement must be based on its performance to execute its function. While its capability to execute its function depends on the physical condition, the operational condition and the load factor (Suprayitno \& Soemitro, 2019).

\subsection{Correlation Analysis}

Correlation Analysis is designated to evaluate whether two variables have certain correlations or not. The two variables can be of parametric or nonparametric variables. These can be of a continuous or deterministic variable. Those can be also as nominal or ordinal variables. The correlation strength is indicated by the coefficient of correlation $r$. The $r$ has a value of -1 to 1 . The more the value is close to 0 , the less correlation strength is. A negative value indicates that the correlation is in a negative direction (Dalati, 2018; Zaid, 2015).

A correlation coefficient formula for continuous nominal variables, known as the Pearson correlation coefficient, is presented below (Zaid, 2015).

$$
r=\frac{\sum\left(x_{i}-\bar{x}\right)\left(y_{i}-\bar{y}\right)}{\sqrt{\sum\left(x_{i}-\bar{x}\right)^{2} \sum\left(y_{i}-\bar{y}\right)^{2}}}
$$

where:

$$
\begin{aligned}
& \mathrm{r} \quad=\text { correlation coefficient } \\
& \mathrm{x}, \mathrm{y}=\text { variables }
\end{aligned}
$$


The formula for non-parametric variables, among others, is Kendall's Tau rank correlation coefficient and Spearman Rank correlation coefficient (Zaid, 2015).

The correlation analysis, in this research, is merely a preliminary study. So, the researchers used a simplified correlation analysis without using any formula mentioned above. A simple dispersion objective value among different independent variables was used.

\section{RESEARCH METHOD}

The correlation analysis was done to obtain the correlation between the Implementation Area Main Characteristics with the Success Value. The Success Value was gotten from questioners asked to the share-holders. Success Value consists of the road physical condition, road utilization and road operation condition. The Area Main Characteristics is expressed in categorical data, while the success value is expressed in ordinal value. The analysis was done by pairing the Characteristics Value (categorical qualitative data) against the Success Value (ordinal data) (Dalati, 2018). The same paired data indicate a tendency that the data are correlated. The result will be an expression of the percentage of achieving certain Success Values for each Area Characteristics Value.

This analysis is neither correlation, regression, nor paired comparison statistical analysis techniques (Zaid, 2015; Manuela, 2011).

\section{RESULT AND DISCUSSION}

\subsubsection{Pasuruan City and NUSP Project}

Pasuruan City, administratively, is a city in East Java Province. It is a very small coastal city, located at Madura Straits, at about $60 \mathrm{~km}$ southeast from Surabaya. Having an area of 36.56 sq.km, the $84^{\text {th }}$ among Indonesian cities, the Pasuruan population is 186.262 in the year 2010. The city is divided into 4 districts, and further divided into 34 villages. Pasuruan City has an intercity bus terminal, a railway station, and a seaport. Located directly south of Madura, a lot of Maduranese people reside in Pasuruan City. Pasuruan City's location in East Java Province is presented in Figure 1 below.

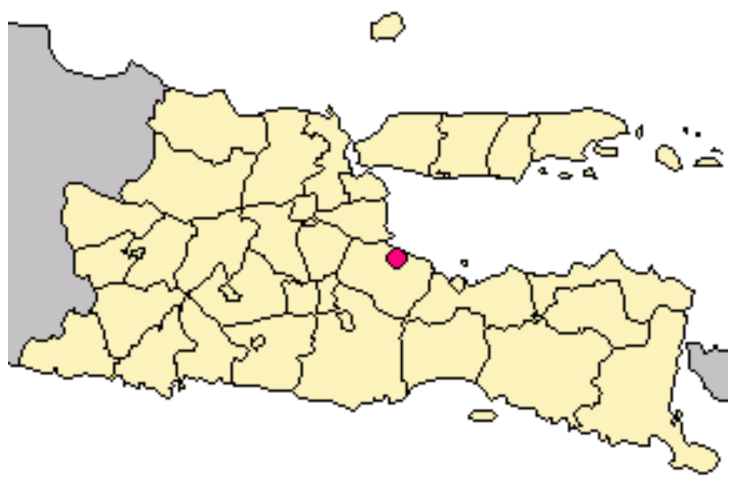

Figure 1. East Java and Pasuruan City 
NSUP and NUSP Program is offered to all cities of Indonesia. The city must make a proposal to be given the program. For the whole of Indonesia, the programs were conducted in more than 20 cities. In East Java Province, it is only Pasuruan City who gets the NUSP, started from 2015 to 2018. The first given NUSP in 2015 covered only 9 villages of Pasuruan City. The research observed the NUSP 2016 covering 11 villages. This NUSP 2016 program dealt with infrastructure community road, community sanitation facility, community water supply facility.

\subsection{NUSP Community Characteristics}

NUSP-2 Year 2016 for Pasuruan

City covered 11 Kelurahans with a slum area. Among the 11 villages, 1 is located in Kecamatan Gadingrejo, and the other 10 are located in Kecamatan Panggungrejo. Among the 11 villages, 4 of them are located in the coastal area as Fisherman Settlement, 3 of them are located next to the coastal area dominated by supporting fisherman activity, and 4 of them are located in the central urban area. The map of the 11 Kelurahans is presented in Figure 2 below. While the area of the village is presented in Table 1 below.

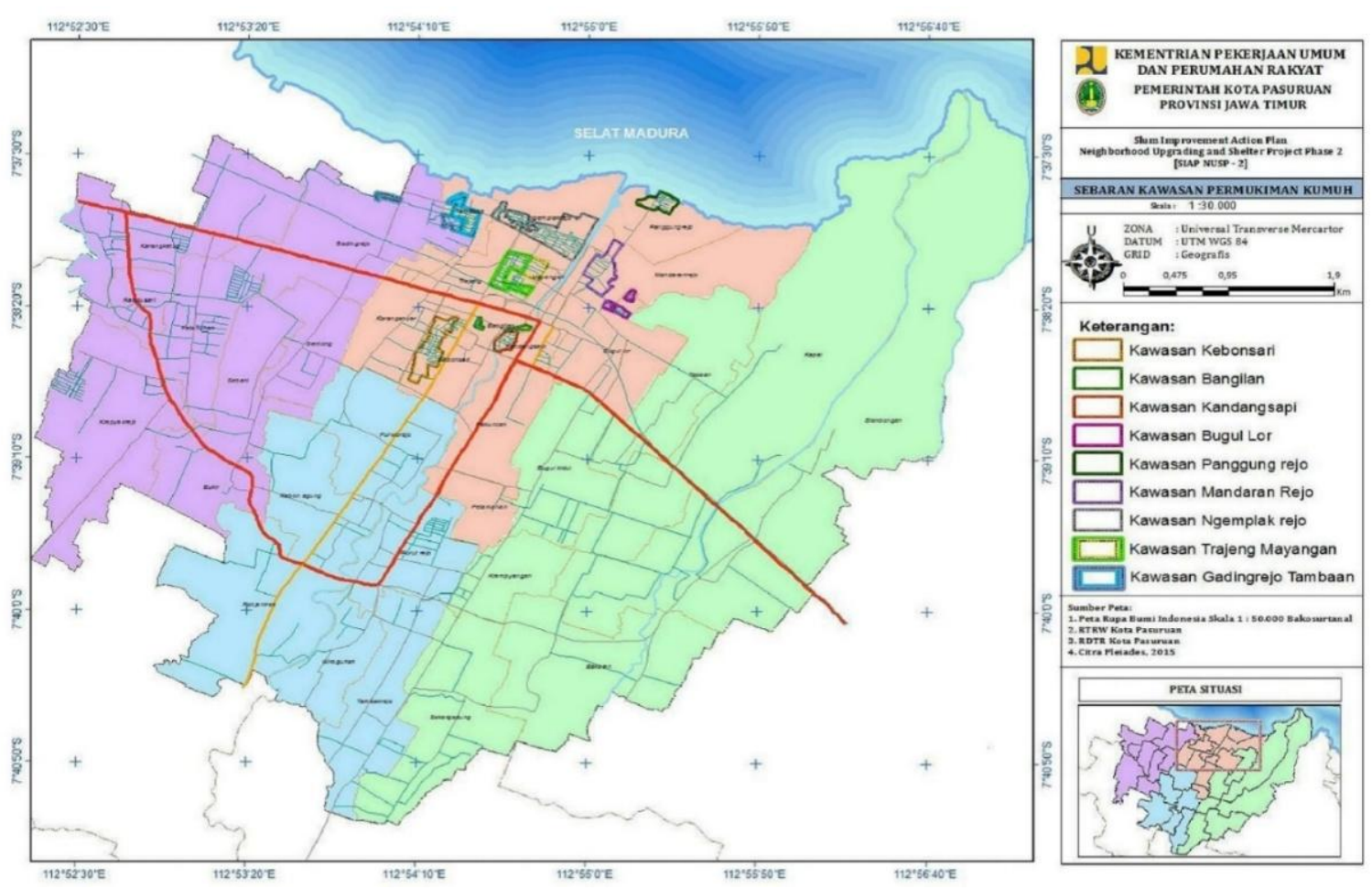

Figure 2. Slum Areas in Pasuruan City for NUSP-2 Year 2016 Project. 
Table 1. Eleven Kelurahans with Slum Area Receiving NUSP-2

\begin{tabular}{|c|c|c|c|}
\hline No & Kecamatan & Kelurahan & Area \\
\hline 1 & \multirow[t]{5}{*}{ Gadingrejo } & Gadingrejo & 5.43 \\
\hline 2 & & Tambaan & 2,14 \\
\hline 3 & & Ngemplakrejo & 19,08 \\
\hline 4 & & Panggungrejo & 4,51 \\
\hline 5 & & Trajeng & 6,76 \\
\hline 6 & \multirow{6}{*}{ Panggungrejo } & Mayangan & 3,38 \\
\hline 7 & & Mandaranrejo & 9,38 \\
\hline 8 & & Bugul Lor & 2,24 \\
\hline 9 & & Kandangsapi & 3,04 \\
\hline 10 & & Bangilan & 1,11 \\
\hline 11 & & Kebonsari & 11,05 \\
\hline
\end{tabular}

The Main Community

Characteristics are divided into Land Use and Activity. The coastal area is filled by fisherman settlement, the next to the coastal area is filled by supporting fisherman activity, and the urban area is filled with family working as an urban worker. The activities in the coastal area are dominated by fishery, in next to the coastal area is dominated by industry, warehouse and trade, while in the urban area is dominated by mix urban activities. These characteristics are presented in Table 2 below.

Table 2. Community Main Characteristics

\begin{tabular}{cllll}
\hline No & Kelurahan & Location & Land Use & Activity \\
\hline 1 & Gadingrejo & Coastal Area & Fisherman Resd. & Port, Fishery, Fisherman \\
2 & Tambaan & Coastal Area & Fisherman Resd. & Port, Fishery, Fisherman \\
3 & Ngemplakrejo & Coastal Area & Fisherman Resd. & Port, Fishery, Fisherman \\
4 & Panggungrejo & Coastal Area & Fisherman Resd. & Port, Fishery, Fisherman \\
5 & Trajeng & Next to Coastal Area & Supp. Fisherman Resid. Industry, Warehouse, Trade \\
6 & Mayangan & Next to Coastal Area & Supp. Fisherman Resid. Industry, Warehouse, Trade \\
7 & Mandaranrejo & Next to Coastal Area & Supp. Fisherman Resid. Industry, Warehouse, Trade \\
8 & Bugul Lor & Urban Area & Urban Residential & Mix urban activities \\
9 & Kandangsapi & Urban Area & Urban Residential & Mix urban activities \\
10 & Bangilan & Urban Area & Urban Residential & Mix urban activities \\
11 & Kebonsari & Urban Area & Urban Residential & Mix urban activities \\
\hline
\end{tabular}

The Economic Level is related to the location, land use, and activity. The coastal area is dominated by Low Income Family (LIF), the next to coastal area starts to have a small proportion of Middle-Income Family (MIF) but has a lot of Low Income
Family (LIF). The urban area has a small amount of Low Income Family LIF) and most of them are the Middle Income Family (MIF). These economic level characteristics are presented in Table 3 below. 
Table 3. Activity and Economic Level

\begin{tabular}{cllll}
\hline No & Kelurahan & Location & Activity & Economic Level \\
\hline 1 & Gadingrejo & Coastal Area & Port, Fishery, Fisherman & LIF \\
2 & Tambaan & Coastal Area & Port, Fishery, Fisherman & LIF \\
3 & Ngemplakrejo & Coastal Area & Port, Fishery, Fisherman & LIF \\
4 & Panggungrejo & Coastal Area & Port, Fishery, Fisherman & LIF \\
5 & Trajeng & Near Coastal Area & Industry, Warehouse, Trade & a lot of LIF + MIF \\
6 & Mayangan & Near Coastal Area & Industry, Warehouse, Trade & a lot of LIF + MIF \\
7 & Mandaranrejo & Near Coastal Area & Industry, Warehouse, Trade & a lot of LIF + MIF \\
8 & Bugul Lor & Urban Area & Mix urban activities & view LIF + MIF \\
9 & Kandangsapi & Urban Area & Mix urban activities & view LIF + MIF \\
10 & Bangilan & Urban Area & Mix urban activities & view LIF + MIF \\
11 & Kebonsari & Urban Area & Mix urban activities & view LIF + MIF \\
\hline
\end{tabular}

\subsection{Road Betterment Program}

The Road Program vary from one village to the others. The number of segments for each village varies from 2 to 9 segments. The road width varies from $0.5 \mathrm{~m}-4.8 \mathrm{~m}$, while the road length varies from $20 \mathrm{~m}-566 \mathrm{~m}$. All of the pavement is of paving block pavement. An example of community road betterment project is presented in Figure 3 below. Example road project location is presented in Figure 4 below. The variation of community roads across different villages is presented in Table 4 below.
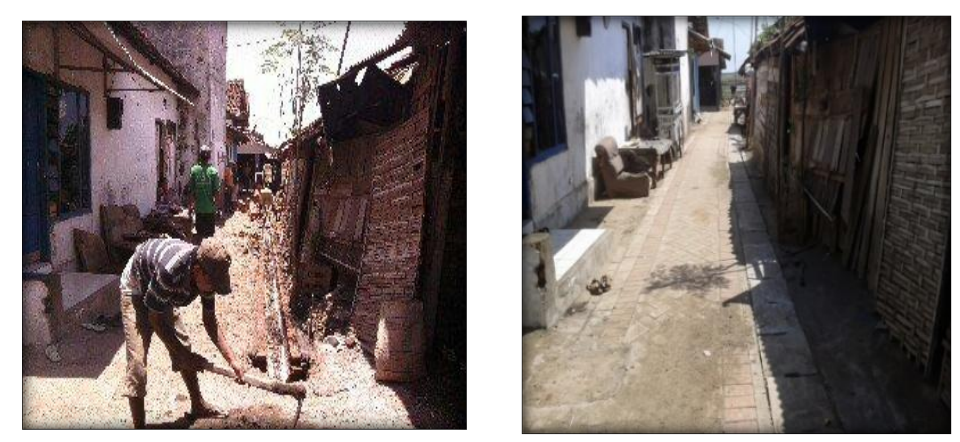

Figure 3. Community Road in Kelurahan Bugul Lor

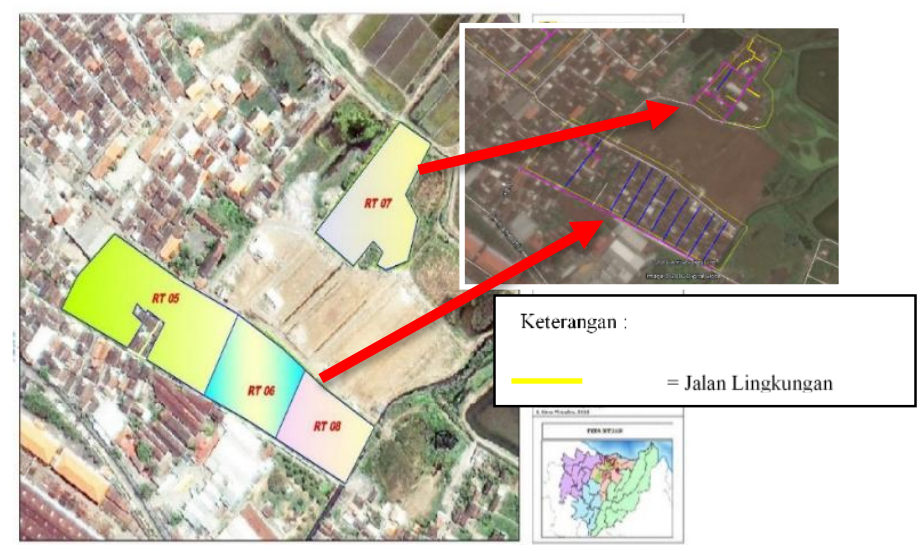

Figure 4. Location Map of Community Road in Kelurahan Bugul Lor 
Table 4. Community Road Betterment Project

\begin{tabular}{clcccc}
\hline \multirow{2}{*}{ No Kelurahan } & \multirow{5}{c}{ Road } \\
\cline { 3 - 6 } & NbrSeg & Pavement & Width & Length \\
\hline & & & $m$ & $m$ \\
\hline 1 & Gadingrejo & 3 & paving & $0.85-2.6$ & $205.7-436$ \\
2 & Tambaan & 2 & paving & $0.6-4.7$ & $277-420$ \\
3 & Ngemplakrejo & 8 & paving & $0.4-4.8$ & $20-254$ \\
4 & Panggungrejo & 7 & paving & 1.2 & $83-355$ \\
5 & Trajeng & 4 & paving & $0.03-2.7$ & $76-232.96$ \\
6 & Mayangan & 4 & paving & 0.08 & $22-224.79$ \\
7 & Mandaranrejo & 7 & paving & $0.35-3$ & $76-483.1$ \\
8 & Bugul Lor & 3 & paving & $0.85-2.60$ & $205.7-436$ \\
9 & Kandangsapi & 6 & paving & $1.25-4.10$ & $27.3-277.5$ \\
10 & Bangilan & 1 & paving & $0.40-3.80$ & 207.3 \\
11 & Kebonsari & 9 & paving & $0.55-4.00$ & $29.6-566.11$ \\
\hline
\end{tabular}

\subsection{Road Program Success Level}

The success of the community road program is measured based on Technical Aspects, i.e. infrastructure performance quality and infrastructure physical quality.
This quality is gotten by direct observation and by synthesizing responses upon questionnaires to the stakeholders. The Evaluation Results are presented in Table 5 below.

Table 5. Project Success Level

\begin{tabular}{clccccc}
\hline \multirow{2}{*}{ No Kelurahan } & \multicolumn{2}{c}{ Community Road Quality } & \multicolumn{2}{c}{$\begin{array}{c}\text { Success } \\
\text { Pevel }\end{array}$} \\
\hline 1 & Gadingrejo & fair & 2 & fair & 2 & 2 \\
2 & Tambaan & bad & 1 & fair & 2 & 1 \\
3 & Ngemplakrejo & bad & 1 & bad & 1 & 1 \\
4 & Panggungrejo & bad & 1 & fair & 2 & 1 \\
5 & Trajeng & good & 3 & good & 3 & 3 \\
6 & Mayangan & fair & 2 & fair & 2 & 2 \\
7 & Mandaranrejo & fair & 2 & good & 3 & 2 \\
8 & Bugul Lor & good & 3 & good & 3 & 3 \\
9 & Kandangsapi & good & 3 & good & 3 & 3 \\
10 & Bangilan & good & 3 & good & 3 & 3 \\
11 & Kebonsari & good & 3 & good & 3 & 3 \\
\hline
\end{tabular}

\subsection{Correlation Analysis}

It is very interesting to observe in pairs the Road Program Success Factor and Area Characteristics. It can be noted that all Local Roads in Urban Residential are in very good condition (Success Level 3). Meanwhile, all Local Roads in Residential with Supporting Fisherman Activity are in fair condition (Success
Level 2), except the one located in Trajeng is in very good condition (Success Level 3). On the other hand, all Local Roads in Fisherman Residential are not in good condition (Success Level 1), except one Local Road located in Gadingrejo is in fair condition (Success Level 2). The Paired Data are presented in Table 6 below. 
Table 6. Correlation between Success and Area Characteristics

\begin{tabular}{clcll}
\hline No. & Location & Success & Location & Land Use Type \\
\hline 1 & Bugul Lor & 3 & Urban Area & Urban Residential \\
2 & Kandangsapi & 3 & Urban Area & Urban Residential \\
3 & Bangilan & 3 & Urban Area & Urban Residential \\
4 & Kebonsari & 3 & Urban Area & Urban Residential \\
5 & Trajeng & 3 & Next to Coastal Area & Supporting Fisherman Residential \\
6 & Mayangan & 2 & Next to Coastal Area & Supporting Fisherman Residential \\
7 & Mandaranrejo & 2 & Next to Coastal Area & Supporting Fisherman Residential \\
8 & Gadingrejo & 2 & Coastal Area & Fisherman Settlement Area \\
9 & Tambaan & 1 & Coastal Area & Fisherman Settlement Area \\
10 & Ngemplakrejo & 1 & Coastal Area & Fisherman Settlement Area \\
11 & Panggungrejo & 1 & Coastal Area & Fisherman Settlement Area \\
\hline
\end{tabular}

The location, land use, activity, and economic level is strongly related to each other. So, here the Land Use is used for Community Main Characteristics. The Urban Residential, dominated by the middle-income family, has $100 \%$ success. The Supporting Fisherman Residential, next to the coastal area, has $67 \%$ medium success and $33 \%$ success. The Fisherman Residential, in the coastal area, has a $75 \%$ fail and $25 \%$ medium success. The Correlation Analysis was done by using the Probability Matrix of Success Value for different Land Use Type. The Urban Residential is Successful, the Supporting Fisherman Residential is Fairly Successful, while the Fisherman Residential is Unsuccessful. This correlation is presented in Table 7 below.

Table 7. Probability Matrix of Success for Different Land Use

\begin{tabular}{clccc}
\hline \multirow{2}{*}{ No } & \multirow{2}{*}{ Land Use } & \multicolumn{3}{c}{ Probability of Success Value } \\
\cline { 3 - 5 } & & $\mathbf{3}$ & $\mathbf{2}$ & $\mathbf{1}$ \\
\hline 1 & Urban Residential & $100 \%$ & - & - \\
2 & Supporting Fisherman Residential & $33 \%$ & $67 \%$ & - \\
3 & Fisherman Residential & - & $25 \%$ & $75 \%$ \\
\hline
\end{tabular}

\subsection{Afterthought}

Even if it was not well investigated and is not part of the paper discussions, revealing the factors and causes of different Success Levels is important. It can be thought that the Low Success Level in the coastal area is due to the education level, the working hours and the family income level. The Madurese fisherman tends to have long working hours, uneducated and very low uncertain income. These influence their behavior of 
not being disciplined, clean, and orderly.

On the other hand, the urban slump area dweller, they are more educated and have more stable work and income. They tend to be more disciplined, clean, and orderly.

After observing in pair the correlation data between Road Program Success Level and the Land Use Type, it can be thought that there must be certain Factors generated by the Area that influence the Road Program Success Level. This needs to be investigated.

\section{CONCLUSIONS}

As the research has been finished, several main and important conclusions can be drawn and presented below.

1. The NUSP-2 of the year 2016 covered 11 Kelurahan in Pasuruan City.

2. Among the 11 villages, 4 villages are in the coastal area, 3 villages are located next to the coastal area, and 4 other villages are located in the urban center area.

3. Among the 11 villages, 4 villages are dominated by fisherman settlements, 3 villages are dominated by supporting fisherman activity, and 4 other villages are dominated by urban area activities.

4. The coastal area is dominated by Low Income Family, the urban center area is dominated by Middle Income Family, while the next to coastal areas are settled by a mix of Low Income Family and Middle Income Family.

5. The road quality is measured by its functional performance and its physical condition, in which the sustainability of function and physical condition is strongly considered.

6. The community road program is relatively good in an urban area dominated by middle-income families, relatively bad in a coastal area dominated by fisherman settlements, and relatively fair in next to the coastal area dominated by supporting fishery activity.

This research induced several further curiosities, i.e. analyzing factors affecting the program success, reflecting the method to define factors.

Notes. This paper was presented in $2^{\text {nd }}$ WUICACE 2019, Warmadewa University, Denpasar-Bali and is part of working papers for developing knowledge on Infrastructure Asset Management. 


\section{REFERENCES}

Bahar, W.S. (2016). Pengembangan Kawasan Wisata Alam Berbasis Partisipasi Masyarakat di Kecamatan Panceng Kabupaten Gresik. Tugas Akhir RP 141501. Jurusan Perencanaan Wilayah dan Kota. Institut Teknologi Sepuluh Nopember (ITS).

Cattelan, Manuela (2011). Models for Paired Comparaison Data: a Review with Emphasis on Dependent Data. Working Paper Series, No. 8, June 2011. Department of Statistical Science. University of Padua, Italy.

Cipta Karya (2018). Sekilas Informasi Program Kota Tanpa Kumuh. Kotaku. Direktorat Jendral Cipta Karya. Jakarta.

Dalati, S. (2018). Measurement and Measurement Scale. In Modernizing the Academic Teaching and Research Environent. Springer International Publishing AG.

Dewi, A.A.I.A.A. (2018). Model Pengelolaan Wilayah Pesisir Berbasis Masyarakat - Community Based Development. Jurnal Penelitian Hukum De Jure, 18 (2), Juni 2018, 163-182.

Hesna, Y., Suradji, A., Rachmadani, S. \& Satria, E.I. (2018). Studi Kesiapan Daerah untuk Investasi Infrastruktur Sosial Berbasis Pembiayaan Non APBN/APBD. Jurnal Manajemen Aset Infrastruktur \& Fasilitas, 2(Khusus), Desember 2018, 9-18.

Kurniasih, D., Setyoko, P.I. \& Imron, M. (2016). Kinerja Kelembagaan Program Sanitasi Lingkungan Berbasis Masyarakat (SLBM). Masyarakat, Kebudayaan dan Politik, 29(1), Tahun 2016, 14-21.
Megawati, V., Pranoto, H.A., Mulya, T.W. \& Prima, D.A. (2018). Kewirausahaan berbasis Komunitas: Model Bisnis unutk Pengelolaan Aset dan Fasilitas. Jurnal Manajemen Aset Infrastruktur \& Fasilitas, 3(2), September 2019, 109-118.

PerMenPR 10/10. Peraturan Menteri Negara Perumahan Rakyat Nomor 10/PErmen $/ \mathrm{m} / 2010$ tentang Acuan Pengelolaan Lingkungan Perumahan Tapak.

PP 14/16. Peraturan Pemerintah Nomor 14 Tahun 2016 tentang Penyelenggaraan Perumahan dan Kawasan Permukiman.

Prakoso, A.A. \& Pravita, V.D. (2018). Model Pengembangan Pariwisata Berbasis Komunitas pada Desa Nelayan di Daerah Istimewa Yogyakarta. Seminar Nasional Pariwisata 15 Desember 2018. Yogyakarta.

PSF (2013). Indonesia: Evaluasi Program Pembangunan Berbasis Masyarakat (CDD) Perkotaan - Program Nasional Pemberdayaan Masyarakat Mandiri Perkotaan (PNPM Urban). Working Report. PNPM Support Facility. Jakarta

Rahmaniyah, Ayu (2019). Faktor Prioritas dalam Keberlanjutan Fungsi Jalan Lingkungan dengan Pengelolaan Berbasis Partisipasi Masyarakat pada Permukiman Kumuh di Kota Pasuruan. Tesis - RC 185401. Departemen Teknik Sipil. FTSLK. Institut Teknologi Sepuluh Nopember (ITS). Surabaya.

Setiawan, Andi (2014). Evaluasi Manfaat Program Sanitasi Lingkungan Berbasis Masyarakat (SLBM) di Kabupaten Bangkalan. EXTRAPOLASI Jurnal Teknik Sipil 
Untag Surabaya, 7(2), Desember 2014, 219-228.

SNI 03-1733-2004. Standar Nasional Indonesia 03-1733-2004 Tata Cara Perencanaan Lingkungan Perumahan di Perkotaan.

Suprayitno, H. (2014). Metoda Penilaian Kualitas Jaringan Jalan Utama di Wilayah Kabupaten. Disertasi $R C$ 09-3399. Jurusan Teknik Sipil. Institut Teknologi Sepuluh Nopember (ITS). Surabaya.

Suprayitno, H. \& Soemitro, R.A.A. (2018). Preliminary Reflexion on Basic Principle of Infrastructure Asset Management. Jurnal Manajemen Aset Infrastruktur \& Fasilitas, 2(1), Maret 2018, 1-10.

Suprayitno, H. \& Soemitro, R.A.A. (2019). Reflection on Basic View Public Infrastructure for Infrastructure Asset Management in Indonesia. Jurnal Manajemen Aset Infrastruktur \& Fasilitas, 3(Sup 1), Juni 2019, 1524.

UU 1/11. Undang Undang Republik Indonesia Nomor 1 Tahun 2011 tentang Perumahan dan Kawasan Permukiman.

Zaid, M.A. (2015). Correlation and Regression Analysis - Textbook. Ankara: SESRIC - Statistical Economic and Social Research and Training Center for Islamic Countries. 